Bojan Mevlja*

Klemen Kavčič ${ }^{* *}$
JEL Classification M1, L3

Preliminary statement

https://doi.org/10.32910/ep.70.2.4

\title{
IMPACT OF STAKEHOLDERS ON THE DEVELOPMENT OF NON-GOVERNMENTAL ORGANISATIONS IN SLOVENIA
}

Unlike profit organisations, which pursue profitable goals under the influence of influential stakeholders, the interests of stakeholders in nongovernmental organisations (NGOs) are much less uniform. The paper aims to focus on the contribution and the characteristics of non-governmental organisations (NGOs) in Slovenia, and the conflicting interests as well as the impact of internal and external stakeholders of NGOs. The purpose of this paper is to conduct an empirical analysis of the key influences of internal and external stakeholders. Our intention is to determine the relations between the interests of influential stakeholders and the performance of the organisations in question, as well as to define the understanding of performance from the viewpoint of NGOs' management. We confirmed the hypothesis proposing that the external influences of stakeholders have a greater impact on the performance than the internal influences. We found out that public relations, advocacy, fundraising and regularity have a statistically significant influence on the NGOs' mission. Complexity and heterogeneity of non-governmental organisations could be counted among the most important research limitations. From the aspect of scientific contribution in the

${ }^{*}$ B. Mevlja, Ph.D., lecturer, University of Primorska, Faculty of Management, Koper, Slovenia (E-mail: bojan.mevlja@fm-kp.si).

** K.Kavčič, Ph.D., full professor, University of Primorska, Faculty of Management, Koper, Slovenia (E-mail: klemen.kavcic@fm-kp.si).

The paper was received on April 9th, 2018. It was accepted for publication on November 23rd, 2018. 
geographical area of Central Europe, i.e. a former communist state, a country in transition economy, it was thus far impossible to find contributions to empirically examine the impact of stakeholders on the development of nongovernmental organisations; therefore, the study described in the article is unique in this area.

Key words: influential stakeholders, management, non-profit organisations, interest, mission.

\section{Introduction}

Nowadays, the global recession causes states to outsource part of their public functions, and so NGOs are taking over some of these responsibilities. We believe that Slovenia still "controls" most of the services in public education, which leads us to believe that the state will "liberalise" the services in this area as well. The Slovene non-governmental educational organisations operating in the field of informal education could thus take over a large part of this type of education. This is also the reason why these organisations were chosen as the subject of our research. Another reason is the fact that, owing to their small size and flexibility, they are in the position to adapt to the needs of the environment in which they operate more successfully than other educational institutions.

Slovenia, the former socialist country and EU member, is one of the countries characterised by a great divide in communication and cooperation as well as poor state control over private non-profit-voluntary organisations (Kolarič, Črnak-Meglič \& Vojnovič, 2002, p. 131). We will first examine NGOs, their particular features, development and existence. Special focus will be placed on non-governmental educational organisations in Slovenia. Based on the findings on non-governmental educational organisations, we will continue by reviewing the establishing of various interests and impacts of stakeholders in NGOs. The empirical part will consist of a quantitative research, in the course of which we will propose a hypothesis. The results obtained in the empirical research will help us understand the roles of external and internal factors of non-governmental educational organisations reflected in the level of the realisation of interests of influential stakeholders.

The paper is organised as follows: After the introductory chapter, the first chapter discusses the literature review and development of NGOs. Chapter two presents the research methodology. The third chapter contains the results and the discussion. The final chapter outlines the most significant conclusions and suggests directions for future research. 


\section{Literature review and theoretical background}

The notion of NGOs comprises two types of organisations. The first are public non-profit organisations established by public institutions, whose mission is to implement the public interest. Then there are private non-profit organisations founded by private natural persons and legal entities, whose mission is to realise the common and/or public interest. Both the public and the common interest represent a legitimate operationalisation of the general social interest (Monnier \& Thiry, 1997, p. 324).

All private NGOs represent "the third sector" and there are researchers around the world who see a resemblance between individual systems. The French économie sociale (Forsé, 1984), the voluntary sector in the UK (Knapp, Robertson \& Thomason, 1990; Ware, 1989), the German gemeinützige Organisationen (Anheier, Hass \& Beller, 2013) and the non-profit sector in the USA (Barman, 2013) display some similarities, which indicate certain commonalities of this sector.

In general, private NGOs can be defined as a broad spectrum of organisations that are neither commercial nor state-owned, but appear in public under different names, such as non-profit, voluntary, humanitarian, independent, civil society, and non-governmental organisations. For the purposes of our research, we will use the term non-governmental organisations.

Additionally, NGOs in post-socialist countries exhibit common characteristics but differ greatly at the same time. These internal similarities and external differences can be explained against the backdrop of the socialist system, which prevailed in these societies for nearly half a century. Following the decline of the socialist system, these societies experienced a booming development of NGOs, but the non-governmental sector in post-socialist countries has remained fairly underdeveloped (Kolarič \& Rakar, 2010).

According to Divjak and Šporar (2006, p. 18-24), it is the countries' welfare systems that determine expenditures for social welfare and the size of the nonprofit sector, i.e. the position of the civil society and community in relation to the market and the state within various welfare systems. It is thus possible to distinguish between liberal, conservative-corporate, social-democratic, Latin-Roman, and communist welfare systems. The communist/socialist type of welfare system was typically present in former socialist societies, in which the communist authorities used the state apparatus to control all aspects of social life. The citizens' self-organisation was therefore limited and the role of the Church marginalised. Within this system, non-governmental organisations acted mainly as supporters of informal social networks. Svetlik (1992) takes a similar view and says that the 
poorly developed non-profit sector in Southern and Eastern Europe can be attributed to the gap between the state and the civil society. The state often assumes the controlling role and thus interferes with and hinders civil society. On the other hand, factors of the civil society remain divided and therefore too weak to be able to effectively address their requirements to the state and for the state to recognise them as equal partners. Salamon, Sokolowski and List (2003, p. 34) believe that, despite considerable growth of the non-governmental sector in the transitional Central and Eastern Europe, non-governmental organisations remain but a pale reflection of similar NGOs around the world, including Latin America and Western Europe. These non-governmental organisations are characterised by low level of professionalisation, dependency on volunteers and small resources. This also applies to non-governmental organisations in the field of education.

Aware of the great divide in the development of NGOs in Europe, the European Union encourages the development of NGOs in all Member States. Lloyd (2004, p. 202) believes that the two elements essential for the development of the non-governmental sector in the European Union have already been applied in the current European politics. The first element relates to social economy, which has already been recognised within regulations on structural funds and employment guidelines. The second element is more indirect and refers to the principle of "acting locally", promoting employment and heavily emphasising local partnerships. Politics thus enables a platform that allows those who wish to encourage measures through a combination of economic and social objectives to take the initiative.

Social economy or social entrepreneurship therefore constitutes a development potential, of which all transition states, such as Croatia, are becoming increasingly aware (Vincetić, Babić \& Baturina, 2013).

In Slovenia, civil society began developing as an alternative rather than the opposition to the official politics. Today, around 26,000 NGOs operate in Slovenia, of which a great majority can be classified under the following legal forms: associations, private institutes and institutions or foundations. In 2012, there were 25,065 NGOs, of which 23,963 were active, meaning they submitted their annual financial reports to the Agency of the Republic of Slovenia for Public Legal Records and Related Services (Agencija Republike Slovenije za javnopravne evidence in storitve [AJPES], 2013). By far the most numerous are associations, totalling at 21,622 , followed by private institutes $(2,111)$ and institutions or foundations $(232)$ (AJPES, 2013). The number of NGOs is constantly on the rise as exhibited by the fact that around 15,500 of them were registered 10 years ago (Forbici, Divjak, Osonkar, Dernovšek \& Verbajs, 2013).

Stakeholders are defined as "any group or individual who can affect or is affected by an organisation's achievements" (Freeman, 1984, p. 46). We expect to find a wide diversity in needs and objectives of non-profit organisation's stakeholders in 
relation to effective governance as they go into partnership with non-profit for different reasons. This expected diversity in needs and objectives between stakeholder groups can be rephrased as the expectation that several needs and objectives of different stakeholder groups can be conflicting, sometimes even mutually harmful. We expect to find diversity in needs and objectives not only across stakeholder groups, but also within some particular stakeholder groups (Eellens \& Jegers, 2014).

As already pointed out, the success of organisations depends on how they adapt and change to accommodate the stakeholders, their influence and interests. Drawing on the stakeholder theory, where profit organisations are viewed in terms of interests, such interests should be regarded as "accountability" within a non-profit organisation - a rather minimalistic definition by Schafer (1999, p. 9). The significance of accountability in maintaining social systems has been known for millennia. In their discussions, early Greek philosophers such as Zeno, Plato, Aristotle and others covered the concepts of accountability, e.g. tributes, justice and the sanctioning of prohibited behaviour (Schlenker, Britt, Pennington, Murphy $\&$ Doherty, 1994, p. 634). The introduction to the reflections on the accountability of NGOs begins with the approach to accountability, which can be introduced with the following question: "Who is accountable to whom, for what and under what conditions?" (Gagne, 1996, p. 213). According to Christensen and Ebrahim (2006, p. 196), accountability refers to the responsiveness of external or internal stakeholders to the actions of an NGO. For the purposes of this research, accountability will be defined as management of various expectations held by stakeholders implemented by the management in NGOs (Kearns, 1996; Romzek \& Dubnick, 1987). Over the last 25 years, we have witnessed a global boom of philanthropy, volunteer work and civil organisations (Salamon, 2010, p. 168). As a result, the interest in the academic research of this area increased as well. Naturally, the greatest number of academic and research work on this subject was carried out in the field of sociology (DiMaggio \& Anheier, 1990). And yet, the field dealing with the interests of stakeholders, i.e. their accountability and influence on the development of NGOs, has been studied much less extensively. As pointed out by Candler \& Dumond (2010, p. 259), there is no lack of research on the non-profit sector; there is, however, only a modest amount of literature dealing directly with the issue of the impact of internal and external stakeholders on operational performance in NGOs.

The authors have also identified various stakeholders in NGOs. Adil Najam (1996, p. 341) thus restricts an NGO's accountability to accountability to its sponsors, beneficiaries and the organisation itself. Brown and Moore (2001, p. 261) proceeded to identify the key stakeholders in NGOs, i.e. beneficiaries, donors and other resource providers, experts/regulators, staff, constituents, policy influence targets, members, the general public and the media. As a starting point for the definition of stakeholders, it should be necessary to consider the findings of Candler and Dumond (2010, p. 262), who define various stakeholders as: members, clients, 
constituents, donors, the government/local community, the general public, the media, staff and partners/allies.

Although we discuss how each stakeholder is responsible for the development of NGOs, we know on the other hand that certain differences or frictions may arise between them. NGOs thus find themselves in a constant process of negotiating between the influences of various external and internal stakeholders (Mumby, 1988; Putnam, 1989). This process is usually coordinated by managers in non-profits, who must possess suitable competences in order to control these influences for the benefit of the organisation. The supervisory or management boards usually play the role of an intermediary between the organisation and the outside environment (Van Puyvelde, Caers, Du Bois \& Jegers, 2012, p. 433). In principle, the relations and conflicts between the external and internal environment in a non-profit are basically defined by two theories, namely the agency theory and the stewardship theory, which are described below. In NGOs, responding to the stakeholders' needs is largely related to achieving their mission and the services they offer (Kanter \& Summers, 1987) or organisational performance influenced by their mission statements (Macedo, Pinho \& Silva, 2016; Patel, Booker, Ramos \& Bart, 2015).

This division originates from the two above-referenced theories, the agency theory and the stewardship theory. In line with the agency theory, managers act solely for their own benefit, in an individualistic, opportunistic and self-sufficient manner (Curcio, 1997; Eisenhardt, 1989; Heinfeld \& Shapiro, 2005; Miller \& Sardais, 2011). According to the stewardship theory, however, they act through self-realisation for the benefit of the company characterised by collectivism and trust (Davis, Schooman \& Donaldson, 1997, p. 37). Proceeding from both theories, it is possible to discern a dual way of treating NGOs or managers. On the one hand, this is reflected as external control over non-profits or their managers to avoid any misuse to the detriment of the organisation's stakeholders. On the other hand, we trust NGOs and their managers to establish a mode of operation, which will be to the benefit of and in line with the needs of the society, reflecting responsibility towards the organisation as a whole.

The Urban Institute and the What Works Centre (2006) have designed a standard model for the development of outcomes and outcome indicators, their aim being to provide important tools that will help increase the value of services rendered by the non-profit sector in public. The model emphasises that the outcomes of a program or service must address the direct interest and concern of service beneficiaries and constituents, whereby the outcomes of a program/service are measured with results and indicators.

Focusing on beneficiaries and community-focused outcomes and results are the main two mechanisms that can protect NGOs from focusing on results that promote only the organisation's survival. For this reason, Standerfer and Schafer 
(2011) designed a model comprising all of the findings that had been set out above, combining the model proposed by Candler and Dumond (2010) with the model proposed by the Urban Institute and the What Works Centre (2006). This model takes into account the logic applied by Candler and Dumond (2010) in terms of accountability to whom and for what, but omits splitting accountability to consequential and procedural accountability. It also omits the logic of measuring inputs and outputs in the organisation, replacing it instead with outcomes and indicators.

It is vital to propose such an accountability model, seeing as this gives rise to a certain amount of autonomy in the development, and is reflected in the outcomes of programs within individual NGOs. What is more, it ensures procedures enabling the influence of external supervision of organisational performance. It seems that both ways are suitable to prevent NGOs from drifting too far from their original mission and spending donor funds, whether this is intentional or not (Standerfer \& Schafer, 2011, p. 12).

The significance of measuring performance in NGOs was already discussed by Kaplan (2001), who applied the balanced scorecard model to the level of NGOs. The model discusses the significance of organisations being aware of the connection between non-financial and non-material dimensions of measuring performance, and the consequences they have on the cash flow (Neely, Marr, Roosm, Pike \& Gupta, 2003). Many other authors also place a lot of importance on the significance of measuring performance in NGOs (Boateng, Akamavi \& Ndoro, 2016; Dacombe, 2011; Greiling, 2010; Hall, 2014; Reheul, Caneghem \& Verbruggen, 2014; Schobel \& Scholey, 2012; Viader \& Espina, 2013) and say that non-financial measures such as management effectiveness, stakeholder involvement, benchmarking (Boateng et al., 2016) and mission statements (S. Pandey, Kim \& S. K. Pandey, 2017) are important to the performance of NGOs

Measuring performance in profit organisations primarily relates to creating financial value for its owners (Munir, Baird \& Perera, 2013; Nicholls, 2009). Measuring performance in NGOs, however, pursues two fundamental goals, namely proving one's worth to stakeholders and improvement of organisational performance through learning from evaluating one's programs and services, and by comparison with others, through internal reporting (Huang \& Hooper, 2011; Saj, 2013). Although financial performance in NGOs is thus not essential, it is still important.

\section{Research methodology}

We used the theoretical platform and the foregoing discussion of literature to research and analyse the key influences of internal and external stakeholders, 
and formulated the hypothesis that the external influences of stakeholders have a greater impact on the performance of Slovene non-governmental educational organisations than internal influences.

\subsection{Sampling and data collection}

The survey in the form of a questionnaire was emailed to managers in private institutes active in the field of education. The contact information on NGOs was obtained through publically accessible databases and the websites of the relevant NGOs. The survey questionnaire consisted of questions relating to the areas of realising different interests of internal and external stakeholders in private institutes in the field of education. The data relating to the performance of NGOs was obtained through secondary sources, i.e. public data available from the Agency of the Republic of Slovenia for Public Legal Records and Related Services (AJPES, 2013); the data includes the operating profit/loss of NGOs from 2008 to 2012. The questionnaire was sent to NGOs in 2014; the data was collected in the course of one month, from 15 June to 15 July. There were 289 such institutes active in 2013 (Bisnode, 2014). Organisations were deemed active if they submitted their financial reports in the past fiscal year. A total of 78 completed questionnaires were returned, however, only 71 questionnaires were usable.

The questionnaire was roughly divided into two sections. The first section comprised statements regarding the importance of the influence of individual practices/mechanisms on the operation of NGOs, where the respondents had to rate, on a scale of 1 (does not apply) to 6 (fully applies), the realisation of various interests of internal and external stakeholders in private institutes in the field of education - program mission/results and self-regulation, reporting and finances, information management, management and human resources, public policies and advocacy. The second section was of a general nature and referred mainly to the respective representative of the NGO's management, who filled out the questionnaire. The survey was sent to be filled out by all registered private institutes engaged in "Other education n.e.c" (Standard Classification of Activities - SKD 85.590). Due to a high degree of heterogeneity among NGOs, and to facilitate result interpretation and international comparability, we focused on private institutes in informal education, since their small size and flexibility help them to adapt to the needs of the environment in which they operate with far greater success. The survey in the form of an online questionnaire was emailed to managers in private institutes active in the field of education. The contact information was obtained through publically accessible databases and the websites of the relevant NGOs. 


\section{Results and discussion}

\subsection{Sample}

Seventy-one respondents participated in the research, of which $63.4 \%$ were women. Most of the respondents (73.2\%) have a university education, $14.1 \%$ hold a master's degree or higher, while $12.7 \%$ of them have completed secondary school education. The respondents have been working at their respective institutes between 0 and 30 years, with an average at $M=7.4$ years (s. d. =6.6), and have been working at their current job at an average of $M=5.8$ years (s. d. $=5.5$ ). The average age of NGOs of their employment is $M=9.2$ years (s. d. $=6.2$ ), with 0 to 61 employees in 2013, an average of $M=3.3$ (s. d. = 8.3). Nearly a quarter of NGOs (23.9\%) holds the status of a voluntary organisation.

\subsection{Descriptive statistics}

In the area of program mission/results and self-regulation, the participating NGOs mostly carry out services in line with the organisation's mission $(\mathrm{M}=5.1)$, in addition to allocating funds to activities important for the organisation's mission $(\mathrm{M}=5.0)$, while the lowest score with regard to the implementation can be attributed to the operations in line with the Code of Ethics \& Conduct for organisations $(\mathrm{M}=3.9)$ and the review and amendment of the organisation's mission by the supervisory body every 3-5 years.

As regards the area of reporting and finances, it fully applies for NGOs that the employees or organisation's management are not given loans $(M=4.8)$, that the operating budget of the organisation is confirmed by a supervisory body $(\mathrm{M}=4.6)$, that the NGOs are adhering to the administrative guidelines of local communities, ministries and the EU ( $\mathrm{M}=4.6)$, while it least applies that they implement annual internal financial audits $(\mathrm{M}=2.7)$ and make the annual financial report available to the wider public $(\mathrm{M}=1.9)$.

As to the information management, the policy of storing documents $(\mathrm{M}=$ 4.2) is realised to the highest degree, while the least is done with regard to the policy of protecting employees who report on the suspicions of the organisation's misconduct $(\mathrm{M}=2.9)$.

As regards the management and human resources in NGOs, it applies that the staff and employees help shape the common vision $(\mathrm{M}=4.9)$, and that the manage- 
ment is susceptible to the opinions, comments and suggestions by the employees $(\mathrm{M}=4.7)$, while it least applies that the supervisory body includes at least three unaffiliated members $(\mathrm{M}=2.6)$.

In terms of public policy and advocacy, it is most true that the NGOs establish and nurture joint partnerships with local communities, government agencies, companies, other NGOs or academic organisations $(\mathrm{M}=5.4)$, while it least applies that they restrict the funds earmarked for lobbying $(M=3.6)$.

\subsection{Multivariate analysis in hypothesis testing}

We carried out two factor analyses, one on the variables referring to the internal factors of stakeholders, while the other was conducted on the variables referring to the external factors. With internal factors, we eliminated the variable "The organisation does not give out loans to employees or company management" due to communality lower than 0.3 . With external factors, we eliminated the variables "Availability of your annual financial report to the wider public (on the website)" (communality < 0.3 ) and "Prohibition of participating in political campaigns" (significant improvement in the reliability of the measuring instrument).

With internal indicators, the determinant value is higher than 0.00001 , the $\mathrm{KMO}$ value $=0.761$, while the Bartlett's Test is statistically significant $(\alpha=0.000)$, meaning that the conditions for the implementation of a factor analysis have been met. Four factors were eliminated, accounting for the $61.3 \%$ of pooled variance. For easier interpretation, we conducted a varimax rotation, and saved the factor analysis results as new variables, which we used in further analysis (Table 1). 


\section{Table 1.}

\section{ROTATED FACTOR MATRIX FOR INTERNAL FACTORS}

\begin{tabular}{|c|c|c|c|c|}
\hline & & & tor & \\
\hline & 1 & 2 & 3 & 4 \\
\hline Transparency of decision-making within the organisation & .859 & & & \\
\hline $\begin{array}{l}\text { Understanding and joint forming of the common vision with staff } \\
\text { and employees }\end{array}$ & .799 & & & \\
\hline $\begin{array}{l}\text { Management's response to opinions, comments and suggestions of } \\
\text { employees }\end{array}$ & .776 & & & \\
\hline Equal employment opportunities (women, the disabled, etc.) & .680 & .510 & & \\
\hline $\begin{array}{l}\text { Established policy for conflicts of interests of organisation's } \\
\text { management }\end{array}$ & .560 & .303 & & \\
\hline $\begin{array}{l}\text { Organisational guidelines ensuring significance, accuracy } \\
\text { and timeliness of information flow through organisation's } \\
\text { communication channels }\end{array}$ & .459 & .401 & -.301 & \\
\hline $\begin{array}{l}\text { Protection policy for employees reporting on suspected } \\
\text { cases of misconduct by the organisation }\end{array}$ & & .770 & & \\
\hline Annual internal financial audits of financial operations & & .751 & & \\
\hline $\begin{array}{l}\text { Financial restrictions in the organisation are documented } \\
\text { within organisational documents }\end{array}$ & & .585 & & \\
\hline $\begin{array}{l}\text { Clear rules that enable professional management of } \\
\text { volunteers and keep them motivated }\end{array}$ & .393 & .550 & & \\
\hline $\begin{array}{l}\text { Allocation of funds to activities that are important for the } \\
\text { organisation's mission }\end{array}$ & & & .825 & \\
\hline $\begin{array}{l}\text { Evaluation of results (tracking the number of } \\
\text { beneficiaries, clients, etc.) }\end{array}$ & & & .786 & \\
\hline $\begin{array}{l}\text { Measuring the achievement of strategic goals through } \\
\text { self-evaluation }\end{array}$ & & & .735 & \\
\hline $\begin{array}{l}\text { Implementing services in line with the organisation's } \\
\text { mission }\end{array}$ & & & .709 & \\
\hline $\begin{array}{l}\text { Organisation's operating budget approved by the } \\
\text { supervisory body (institute's council) }\end{array}$ & & & & .952 \\
\hline $\begin{array}{l}\text { Review and amendment (if necessary) of the } \\
\text { organisation's mission by the organisation's supervisory } \\
\text { body (institute's council) every } 3-5 \text { years }\end{array}$ & .335 & & & .595 \\
\hline $\begin{array}{l}\text { Supervisory body (institute's council) includes at least } \\
\text { three unaffiliated members }\end{array}$ & & & & .498 \\
\hline
\end{tabular}

Source: Authors' calculations 
Factor No. 1: Decision-making (managing):

- Transparency of decision-making within the organisation

- Understanding and co-shaping of a vision by the staff and employees

- Management's response to opinions, comments and suggestions of employees

- Equal employment opportunities (women, the disabled, etc.)

- Established policy for conflicts of interests of organisation's management

- Organisational guidelines ensuring significance, accuracy and timeliness of information flow through organisation's communication channels

Factor No. 2: Regularity (rules):

- Protection policy for employees reporting on suspected cases of misconduct by the organisation

- Annual internal financial audits of financial operations

- Financial restrictions in the organisation are documented within organisational documents.

- Clear rules that enable professional management of volunteers and keep them motivated

Factor No. 3: Mission (coming up with new ideas):

- Allocation of funds to activities that are important for the organisation's mission

- Evaluation of results (tracking the number of beneficiaries, clients, etc.)

- Measuring the achievement of strategic goals through self-evaluation

- Implementing services in line with the organisation's mission

Factor No. 4: Internal supervision (control):

- Organisation's operating budget approved by the supervisory body (institute's council)

- Review and amendment (if necessary) of the organisation's mission by the organisation's supervisory body (institute's council) every 3-5 years

- Supervisory body (institute's council) includes at least three unaffiliated members. 


\section{Table 2.}

\section{ROTATED FACTOR MATRIX FOR EXTERNAL FACTORS}

\begin{tabular}{|c|c|c|c|c|}
\hline & \multicolumn{4}{|c|}{ Factor } \\
\hline & 1 & 2 & 3 & 4 \\
\hline $\begin{array}{l}\text { Donations are used in line with the restrictions set by the } \\
\text { donor }\end{array}$ & .802 & & & \\
\hline $\begin{array}{l}\text { Operations in line with the Code of Ethics \& Conduct for } \\
\text { organisations (Code of Ethics for Organised Volunteering, } \\
\text { Quality Standard for NGOs) }\end{array}$ & .664 & .341 & & \\
\hline $\begin{array}{l}\text { Sending written thank-you notes/receipts for donations of all } \\
\text { sizes }\end{array}$ & .650 & & & \\
\hline $\begin{array}{l}\text { Ensuring transparency in managing membership fees, } \\
\text { donations and subsidies }\end{array}$ & .574 & & .302 & \\
\hline $\begin{array}{l}\text { Fundraisers do not accept payment based on } \\
\text { commission/percentage of funds raised }\end{array}$ & .551 & & & \\
\hline Policy of document-keeping & .504 & & & .385 \\
\hline $\begin{array}{l}\text { Organisational information on the operations and activities } \\
\text { available to the public }\end{array}$ & & .803 & & \\
\hline $\begin{array}{l}\text { PR policy enabling access to/submission of information on } \\
\text { organisation's activities/operations }\end{array}$ & .395 & .784 & & \\
\hline $\begin{array}{l}\text { Policy of confidentiality with regard to donors, clients, } \\
\text { employees and volunteers }\end{array}$ & & .628 & & \\
\hline $\begin{array}{l}\text { Complaint-related guidelines for client and employee } \\
\text { conduct in the event of complaints }\end{array}$ & & .591 & & .306 \\
\hline Policy of acceptable gifts & .355 & .421 & & \\
\hline $\begin{array}{l}\text { Establishing and nurturing joint partnerships with local } \\
\text { communities, government agencies, companies, other non- } \\
\text { governmental organisations or academic organisations } \\
\text { (universities, faculties, institutes, etc.) }\end{array}$ & & & .775 & \\
\hline $\begin{array}{l}\text { Participation of employees, volunteers, etc. in public policy } \\
\text { procedures }\end{array}$ & .319 & & .663 & \\
\hline $\begin{array}{l}\text { Keeping up with changes and novelties related to the area in } \\
\text { which the organisation/sector operates }\end{array}$ & & & .540 & \\
\hline $\begin{array}{l}\text { Considering administrative guidelines of local communities, } \\
\text { ministries and the European Union, including the general } \\
\text { reporting duty }\end{array}$ & & .503 & .512 & \\
\hline Limiting resources earmarked for lobbying & & & & .795 \\
\hline $\begin{array}{l}\text { Adhering to the Integrity and Prevention of Corruption Act in } \\
\text { the event of lobbying }\end{array}$ & .380 & & & .676 \\
\hline
\end{tabular}

Source: Authors' calculations 
Reliability was verified by means of the Cronbach's alpha coefficient, which amounts to $\alpha=0.888$ for factor No. $1, \alpha=0.809$ for factor No. $2, \alpha=0.885$ for factor No. 3 and $\alpha=0.714$ for factor No. 4 . The total reliability of internal factors amounts to $\alpha=0.866$.

With external indicators, the determinant value is higher than 0.00001 , the $\mathrm{KMO}$ value $=0.766$, while the Bartlett's Test is statistically significant $(\alpha=0.000)$. The four factors have own value higher than 1, accounting for the 55.5\% of pooled variance. We have applied the varimax rotation and kept the factors as new variables which we needed to conduct further analysis. The variables were classified by factors as follows (Table 2).

Factor No. 1: Fundraising:

- Donations are used in line with the restrictions set by the donor.

- Operations in line with the Code of Ethics \& Conduct for organisations (Code of Ethics for Organised Volunteering, Quality Standard for NGOs)

- Sending written thank-you notes/receipts for donations of all sizes

- Ensuring transparency in managing membership fees, donations and subsidies

- Fundraisers do not accept payment based on commission/percentage of funds raised.

- Policy of document-keeping

Factor No. 2: Public relations:

- Organisational information on the operations and activities available to the public

- PR policy enabling access to/submission of information on organisation's activities/operations

- Policy of confidentiality with regard to donors, clients, employees and volunteers

- Complaint-related guidelines for client and employee conduct in the event of complaints

- Policy for acceptable gifts.

Factor No. 3: Advocacy:

- Establishing and nurturing joint partnerships with local communities, government agencies, companies, other non-governmental organisations or academic organisations (universities, faculties, institutes, etc.) 
- Participation of employees, volunteers, etc. in public policy procedures

- Keeping up with changes and novelties related to the area in which the organisation/sector operates

- Considering administrative guidelines of local communities, ministries and the European Union, including the general reporting duty

Factor No. 4: Integration:

- Limiting resources earmarked for lobbying

- Adhering to the Integrity and Prevention of Corruption Act in the event of lobbying

The Cronbach's alpha coefficient amounts to $\alpha=0.803$ for factor No. $1, \alpha=$ 0.828 for factor No. $2, \alpha=0.725$ for factor No. 3 and $\alpha=0.709$ for factor No. 4 . The total reliability of external factors amounts to $\alpha=0.876$.

To verify the hypothesis, we applied the regression analysis where the dependent variable was represented by the mission factor, while independent variables were represented by all the dimensions of external factors and the remaining three dimensions of internal factors. We applied the Enter method which keeps all the included independent variables in the model.

In verifying the hypothesis, we applied a multiple regression analysis to ascertain the correlation between the mission and the influences of internal and external stakeholders. The regression model proved to be significant $(\mathrm{F}=6.752, \mathrm{p}=0.000)$. The corrected coefficient of determination amounts to 0.365 , which means that $36.5 \%$ of variation by the dependent variable can be accounted for through independent variables included in the model. The Durbin-Watson Test also gives us optimum results around the value of 2 . Correlation between the independent variables and the dependent variable - mission amounts to 0.655. 
Table 3.

\section{REGRESSION MODEL}

\begin{tabular}{|l|r|r|r|r|r|}
\hline & \multicolumn{2}{|c|}{$\begin{array}{c}\text { Non-standardised } \\
\text { coefficient }\end{array}$} & \multicolumn{1}{c|}{$\begin{array}{c}\text { Standardised } \\
\text { coefficient }\end{array}$} & \multicolumn{1}{c|}{$\mathbf{t}$} & \multirow{2}{*}{ sig } \\
\cline { 2 - 4 } & \multicolumn{1}{c|}{$\mathrm{B}$} & \multicolumn{1}{c|}{ St. error } & \multicolumn{1}{c|}{ Beta } & & \\
\hline Constant & .007 & .095 & & .071 & .944 \\
\hline INT1 Decision-making & -.156 & .116 & -.156 & -1.350 & .182 \\
\hline INT2 Regularity & -.308 & .136 & $\mathbf{- . 3 0 4}$ & -2.256 & $\mathbf{. 0 2 8}$ \\
\hline INT4 Internal control & -.133 & .123 & -.133 & -1.086 & .282 \\
\hline EXT1 Public relations & .578 & .114 & $\mathbf{. 5 7 4}$ & 5.083 & $\mathbf{. 0 0 0}$ \\
\hline EXT2 Fundraising & .306 & .139 & $\mathbf{. 3 0 4}$ & 2.209 & $\mathbf{. 0 3 1}$ \\
\hline EXT3 Advocacy & .387 & .105 & $\mathbf{. 3 8 4}$ & 3.696 & $\mathbf{. 0 0 0}$ \\
\hline EXT4 Integration & -.099 & .114 & -.099 & -.869 & .388 \\
\hline
\end{tabular}

Source: Authors' calculations

It was established that the mission in NGOs is influenced with statistical significance (at a 5\% risk rate) by three external factors (public relations, advocacy and integration) and one internal factor (regularity). The greatest influence (in view of the beta value) on the dependent variable is that of public relations, followed by advocacy (Table 3).

The standardised regression coefficient for regularity amounts to -0.304 and has a statistically significant (sig. 0.028) negative influence on the explaining of the dependent variable - mission. The standardised regression coefficient for public relations amounts to 0.574 and has a statistically significant (sig. 0.000) influence on the explaining of the dependent variable - mission. The same is true of the standardised regression coefficient for advocacy, which amounts to 0,384 and has a statistically significant (sig. 0.004) influence on the explaining of the dependent variable - mission. The standardised regression coefficient for fundraising amounts to 0.304 and has a statistically significant (sig. 0.031) influence on the explaining of the dependent variable - mission. The summary of the regression model can be found below.

The hypothesis is confirmed and we can state that the external influences of stakeholders have a greater impact on the performance of Slovene non-governmental educational organisations than the internal influences. It was proven in the course of the analysis that the internal factors are statistically insignificant. Mission is most heavily influenced by the external factor of public relations (beta=0.574), 
followed by advocacy (beta=0.293) and fundraising (beta=0.304), while the negative influence is attributed to the internal factor of regularity (beta=-0.304).

By applying the factor analysis, we designed four factors for internal and four factors for external factors. With regard to internal factors (decision-making, regularity, mission and internal control), we can account for a pooled variance of $61.3 \%$, and for pooled variance of $55.5 \%$ with regard to external factors (fundraising, public relations, advocacy, integration).

By means of the regression analysis, we found out that public relations, advocacy, fundraising and regularity have a statistically significant influence on the NGO's mission, and we used four factors (three external and one internal) to account for $36.5 \%$ of the dependent variable's variability. We can thus confirm the hypothesis proposing that the external influences of stakeholders have a greater impact on the performance of Slovene non-governmental educational organisations than the internal influences. In the course of the analysis, we realised that the balance sheet data do not play an important role in NGOs, thus prompting us to abandon performance measuring through the spectrum of financial performance. The current analysis is oriented towards treating mission as the key measure of NGOs' success.

From the aspect of scientific contribution in the geographical area of Central Europe, i.e. a former communist state, a country in transition economy, we were thus far unable to find any scientific articles which empirically examine the impact of stakeholders on the development of non-governmental organisations; the study provided by the article is therefore unique in this area.

\section{Conclusion}

Non-governmental organisations are not-for-profit organisations, which, during the time of economic recession, share their fate with for-profit organisations. More and more often, governments seek help from non-governmental organisations with regard to the implementation of policies and state's capacity building. Despite the lack of financial resources, this is clearly an opportunity for non-governmental organisations to show how important they are for the development of the society as a whole, provided they are able to quickly adapt to the needs. The research of non-governmental organisations is also important, because it emphasises the importance of different impacts on operations of organisations.

This study was designed to provide insight into the impact of important stakeholders on the development of non-governmental educational organisations in Slovenia. Our results present a foundation for understanding the conflicting 
interests as well as the impact of internal and external stakeholders of NGOs in a new European Member State (e.g. transition countries).

Survey results lead us to conclude that public relations, advocacy, fundraising and regularity have a statistically significant influence on the NGOs' mission. In the course of the analysis, we realised that the balance sheet data do not play an important role in NGOs, thus prompting us to abandon performance measuring through the spectrum of financial performance. The current analysis is oriented towards treating mission as the key measure of NGOs success.

Both complexity and the heterogeneity of non-governmental organisations could be counted among the most important research limitations. Another limitation is the sample, which is limited to private non-governmental educational organisations. In addition, these non-governmental organisations operate in different fields of activity, which is why it would be sensible, in order to confirm our findings, to replicate our research with a sample of non-governmental organisations coming from a different field of activity, e.g. social security or environment.

Last but not least, Slovenia is a former socialist country. Any generalisations derived from the findings are thus limited to countries having a similar social system (e.g. Croatia, Serbia), due to distinct country development paths within the socialist regime. Future studies might expand the research by including other geographic regions.

\section{References:}

AJPES. (2013). Annual reports database. Ljubljana: Agencija Republike Slovenije za javnopravne evidence in storitve (The Agency of the Republic of Slovenia for Public Legal Records and Related Services) (AJPES).

Anheier, H. K., Hass, R., \& Beller, A. (2013). Accountability and Transparency in the German Nonprofit Sector: A Paradox? International Review of Public Administration, 18 (3), 96-105. Available at: https://doi.org/10.1080/1229465 9.2013.10805264

Boateng, A., Akamavi, R. K., \& Ndoro, G. (2016). Measuring performance of non-profit organisations: evidence from large charities. Business Ethics: A European Review, 25(1), 59-74. Available at: https://doi.org/10.1111/ beer. 12108

Brown, D.L., \& Moore, M.H. (2001). Accountability, strategy, and international non-governmental organisations. Nonprofit and Voluntary Sector Quarterly 30 (3), 569-87. Available at: https://doi.org/10.1177\%2F0899764001303012 
Candler, G., \& Dumont, G. (2010). A non-profit accountability framework. Canadian Public Administration 53 (2), 259-279. Available at: https://doi. org/10.1111/j.1754-7121.2010.00126.x

Christensen, R.A., \& Ebrahim A. (2006). How Does Accountability Affect Mission? The Case of a Nonprofit Serving Immigrants and Refugees. Nonprofit Management and Leadership 17 (2).195-209. Available at: https:// doi.org/10.1002/nml.143

CNVOS (2013). Data about NGOs in Slovenia. Accessible in own archive.

Dacombe, Rod. (2011). Can we argue against it? Performance management and state funding of voluntary organisations in the UK. Public Money \& Management, 31(3), 159-166. Available at: https://doi.org/10.1080/0954096 2.2011.573224

Davis, J. H., Schooman, D. F., \& Donaldson, L. (1997). Toward a stewardship theory of management. The Academy of Management Review, 22 (1), 20-47. Available at: https://doi.org/10.5465/amr.1997.9707180258

DiMaggio, P. J., \& Anheier, H. K. (1990). The Sociology of Nonprofit Organisations and Sectors. Annual Review of Sociology. Vol. 16, 137-159. Available at: https://doi.org/10.1146/annurev.so.16.080190.001033

Klenovšek, T., Grafenauer B., Divjak T., Verbajs M., Strojan T., Vrbica S. \& Šporar S. (2006): Celovita analiza pravnega okvirja za delovanje nevladnih organizacij. Maribor: Pravna fakulteta.

Eisenhardt, K. M. (1989). Agency Theory: An Assessment and Review. The Academy of Management Review, 14 (1), 57-74. Available at:

https://doi.org/10.5465/amr.1989.4279003

Forbici, G., Divjak, T., Osonkar, B., Dernovšek, V. \& Verbajs, M. (2010). Skupaj za skupnost: priročnik o sodelovanju med občinami in nevladnimi organizacijami. Ljubljana: Zavod Center za informiranje, sodelovanje in razvoj nevladnih organizacij CNVOS. Available at: https:/issuu.com/moja-druzba/docs/ prirocnik-o-sodelovanju-med-obcinami-in-nevladnimi

Forsé, M. (1984). Le creation d'associations: Un indicateur de changement social. Observations et Diagnostics Economiques, 6 (1), 125-45. Available at: https://doi.org/10.3406/ofce.1984.972

Freeman, E. R. (1984). Strategic Management: A stakeholder approach. Boston: Pitman.

Gagne, R.L. (1996). Accountability and public administration. Canadian Public Administration, 39 (2), 213-225. Available at: https://doi. org/10.1111/j.1754-7121.1996.tb00127.x 
Greiling, D. (2010). Balanced scorecard implementation in German non-profit organisations. International Journal of Productivity and Performance Management, 59 (6), 534-554. Available at: https://doi.org/10.1108/17410401011063939

Bisnode. (2014). Bisnode - GVIN. "Pro search engine for finding financial data of businesses". Accessed on 19 March 2014. http://www.gvin.com/ FinancniPodatki/Default.aspx?Stran=ProIs

Hall, M. (2014). Evaluation Logics in the Third Sector. Voluntas: International Journal of Voluntary and Nonprofit Organisations. 25 (2), 307-336. Available at: https://doi.org/10.1007/s11266-012-9339-0

Heinfeldt, J., \& Curcio, R. (1997). Employee management strategy, stakeholder agency theory, and the value of the firm. Journal of Financial And Strategic Decisions, 10(1), 67-75. Available at: http://citeseerx.ist.psu.edu/viewdoc/do wnload?doi=10.1.1.201.7023\&rep=rep1\&type $=$ pdf

Huang, H. J., \& Hooper, K. (2011). New Zealand funding organisations: how do they make decisions on allocating funds to not-for-profit organisations? Qualitative Research in Accounting \& Management, 8 (4), 425-449. Available at: https://doi.org/10.1108/11766091111189909

Kanter, R. M., \& Summers, D. V. (1987). Doing well while doing good: Dilemmas of performance measurement in nonprofit organisations and the need for a multiple-constituency approach. In: W. W. Powell (Ed.), The nonprofit sector: A research handbook (pp. 154-166). New Haven, CT: Yale University Press.

Kaplan, R. S. (2001). Strategic Performance Measurement and Management in Nonprofit Organisations. Nonprofit Management and Leadership, 11(3), 353-370. Available at: https://doi.org/10.1002/nml.11308

Kearns, K. P. (1996). Managing for accountability: preserving the public trust in public and nonprofit organisations. San Francisco: Jossey-Bass Publishers.

Knapp, M., Robertson, E., \& Thomason, C. (1990). Public money, voluntary action: Whose welfare? In: H. K. Anheier, \& W. Seibel (Eds.), The Third Sector: Comparative Studies of Nonprofit Organisations (pp. 183-218). Berlin, New York, NY: De Gruyter.

Kolarič, Z., \& Rakar, T. (2010). Vloga in pomen zasebnega neprofitnega sektorja v Sloveniji. In: International conference "Krepitev dialoga in vloge NVO $v$ javnem zdravju v Republiki Sloveniji in Evropski uniji”, 26 March 2010, Ljubljana. Predstavitve in povzetki (pp. 16). Ljubljana: EPHA: Slovenska zveza za tobačno kontrolo.

Kolarič, Z., Črnak-Meglič, A., \& Vojnovič, M. (2002). Zasebne neprofitno-volonterske organizacije $v$ mednarodni perspektivi. Ljubljana: Fakulteta za družbene vede. 
Macedo, I. M., Pinho, J. C., \& Silva, A. M. (2016). Revisiting the link between mission statements and organisational performance in the non-profit sector: The mediating effect of organisational commitment. European Management Journal, 34(1), 36-46. Available at: https://doi.org/10.1016/j.emj.2015.10.003

Miller, D., \& Sardais, C. (2011). Angel Agents: Agency Theory Reconsidered. Academy of Management Perspectives. 25 (2), 6-13. Available at: https://doi. org/10.5465/amp.25.2.6

Monnier, L. \& Thiry, B. (1997). Mutations structurelles intérêtgénéral: vers quels nouveaux paradigmes pour l'économiepublique, sociale et coopérative? Paris: Ciriec International; Bruxelles: De Boeckuniversité.

Mumby, D. K. (1988). Communication and power in organisations: Discourse, ideology, and domination. Norwood, New Jersey: Ablex.

Munir, R., Baird, K. \& Perera, S. (2013). Performance measurement system change in an emerging economy bank. Accounting, Auditing \& Accountability Journal, 26 (2), 196-233. Available at: https://doi.org/10.1108/09513571311303710

Najam, A. (1996). NGO accountability: A conceptual framework. Development Policy Review 14 (3), 339-354. Available at: https:/doi. org/10.1111/j.1467-7679.1996.tb00112.x

Neely, A., Marr, B., Roosm, G., Pike, S., \& Gupta, O. (2003). Towards the third generation of performance measurement. Controlling, (3/4), 129-135. Available at: https://doi.org/10.15358/0935-0381-2003-3-4-129

Pandey, S., Kim, M., \& Pandey, S. K. (2017). Do mission statements matter for nonprofit performance? Insights from a study of US performing arts organisations. Nonprofit Management and Leadership, 27(3), 389-410. Available at: https://doi.org/10.1002/nml.21257

Patel, B. S., Booker, L. D., Ramos, H. M., \& Bart, C. (2015). Mission statements and performance in non-profit organisations. Corporate Governance, 15(5), 759-774. Available at: https://doi.org/10.1108/CG-07-2015-0098

Putnam, L. (1989). Negotiation and organizing: Two levels of analysis within the Weickian model. Communication Studies, 40 (4), 249-257. Available at: https://doi.org/10.1080/10510978909368278

Reheul, A, Caneghem, T. \& Verbruggen, S. (2014). Financial Reporting Lags in the Non-profit Sector: An Empirical Analysis. Voluntas: International Journal of Voluntary and Nonprofit Organisations 25 (2), 352-377. Available at: https://doi.org/10.1007/s11266-012-9344-3

Romzek, B. S., \& Melvin, J. D. (1987). Accountability in the public sector: lessons from the Challenger tragedy. Public Administration Review, 47 (3), 227-238. Available at: https://doi.org/10.2307/975901 
Saj, P. (2013). Charity performance reporting: comparing board and executive roles. Qualitative Research in Accounting \& Management, 10 (3/4), 347368. Available at: https://doi.org/10.1108/QRAM-05-2013-0018

Salamon, L. M., Sokolowski, W. S. \& List R. (2003). Global Civil Society. An Overview. The Johns Hopkins Comparative Nonprofit Sector Project. Baltimore: Center for Civil Society Studies, The Johns Hopkins University.

Salamon, L.M. (2010). Putting the civil society sector on the economic map of the world. Annals of Public and Cooperative Economics. 81 (2), 167-210. Available at: https://doi.org/10.1111/j.1467-8292.2010.00409.x

Schafer, A. (1999). A wink and a Nod: A Conceptual Map of Responsibility and Accountability in Bureaucratic Organisations. Canadian Public Administration, 42 (1), 5-25. Available at: https://doi.org/10.1111/j.1754-7121.1999.tb01545.x

Schlenker, B.R., Britt, T.W., Pennington, J., Murphy, R., \& Doherty, K. (1994). The triangle model of responsibility. Psychological Review 101 (4), 632-652. Available at: https://doi.org/10.1037/0033-295X.101.4.632

Schobel, K., \& Scholey, C. (2012). Balanced Scorecards in education: focusing on financial strategies, Measuring Business Excellence, 16 (3), 17-28. Available at: https://doi.org/10.1108/13683041211257385

Shapiro, P.S. (2005). Agency Theory. Annual Review of Sociology (31), 263-284. Available at: https://doi.org/10.1146/annurev.soc.31.041304.122159

Standerfer, C., \& Schaefer, J. (2011). Holding non-profits accountable: Frameworks that distinguish between looking good and doing good. In Improving the Quality of Public Services: A Multinational Conference on Public Management, Moscow, Russia. Available at: http://www.umdcipe.org/conferences/Moscow/papers/HOLDING_NONPROFITS_ACCOUNTABLE_FRAMEWORKS_THAT_DISTINGUISH_BETWEEN_LOOKING_ GOOD_AND_DOING_GOOD_.pdf

Svetlik, I. (1992). Slovenia - a portrait of a new European country. In: Social policy in Slovenia: between tradition and innovation, Ed. Ivan Svetlik, 1-14. Aldershot: Avebury.

Van Puyvelde, S., Caers, R., Du Bois, C. \& Jegers, M. (2012). The Governance of Nonprofit Organisations: Integrating Agency Theory with Stakeholder and Stewardship Theories. Nonprofit and Voluntary Sector Quarterly, 41 (3), 431-451. Available at: https://doi.org/10.1177/0899764011409757

Viader, A.M. \& Espina, M.I. (2013). Are not-for-profits learning from for-profitorganisations? A look into governance. Corporate Governance, 14 (1), 1-14. Available at: https://doi.org/10.1108/CG-11-2012-0083 
Vincetić, V., Babić, Z., \& Baturina, D. (2013). Definiranje područja i potencijal razvoja socijalnog poduzetništva Hrvatske u komparativnom kontekstu. Ekonomski pregled, 64(3), 256-278. Available at: http://hrcak.srce.hr/ file/155203

Ware, A. (1989). Between Profit and State: Intermediate Organisations in Britain and the United States. Cambridge: Polity.

\title{
UTJECAJ INTERESNO-UTJECAJNIH SKUPINA NA RAZVOJ NEVLADINIH ORGANIZACIJA U SLOVENIJI
}

\begin{abstract}
Sažetak
Za razliku od profitnih organizacija koje ostvaruju profitabilne ciljeve pod utjecajem snažnih interesno-utjecajnih skupina, interesi interesno-utjecajnih skupina u nevladinim organizacijama mnogo su manje ujednačeni. Cilj rada je fokusirati se na doprinos i obilježja nevladinih organizacija u Sloveniji, na sukobljene interese kao i na utjecaj unutarnjih i vanjskih interesno-utjecajnih skupina nevladinih organizacija. Svrha ovog rada je provesti empirijsku analizu ključnih utjecaja unutarnjih i vanjskih interesno-utjecajnih skupina. Namjera je utvrditi odnose između interesa utjecajnih vanjskih interesno-utjecajnih skupina i poslovanja organizacija o kojima je riječ, kao i definirati razumijevanje poslovanja iz perspektive menadžmenta nevladinih organizacija. Potvrdili smo hipotezu kako vanjski utjecaji interesno-utjecajnih skupina imaju veći utjecaj na poslovanje od unutarnjih utjecaja. Otkrili smo da odnosi s javnošću, aktivizam, prikupljanje sredstava i konzistentnost imaju statistički značajan utjecaj na misiju nevladinih organizacija. Složenost i heterogenost nevladinih organizacija mogu se ubrojiti u najvažnija ograničenja istraživanja. S aspekta znanstvenog doprinosa na području Srednje Europe, u bivšoj komunističkoj, tranzicijskoj zemlja je dosada bilo nemoguće pronaći doprinos koji empirijski ispituje utjecaj interesno-utjecajnih skupina na razvoj nevladinih organizacija, stoga je opisano istraživanje jedinstveno u ovom području.
\end{abstract}

Ključne riječi: snažne interesno-utjecajne skupine, menadžment, neprofitne organizacije, interes, misija. 